\title{
BEZROBOCIE INSTYTUCJONALNE W TEORII I PRAKTYCE GOSPODAROWANIA
}

\section{WSTĘP}

Ekonomia instytucjonalna ${ }^{1}$ analizuje zależności występujące w systemie funkcjonowania gospodarek i ich otoczeniu instytucjonalnym. System ekonomiczny to bowiem zbiór wzajemnie powiązanych instytucji oraz zasad określających przestrzeń zachowań podmiotów gospodarczych ${ }^{2}$. Jak zauważa przy tym M.G. Woźniak, „ład instytucjonalny jest wyznacznikiem sprawności systemu ekonomicznego, a sprawność ta materializuje się poprzez jego zdolność do efektywności ekonomicznej, stabilizacji procesów realnych i mechanizmu funkcjonowania gospodarki, wzrostu gospodarczego, równowagi ekonomicznej oraz generowania sprawiedliwych, tj. ekonomicznie uzasadnionych i społecznie akceptowalnych nierówności dochodowo-majątkowych"3.

Jak dowodzi zaś A. Alchian w Pricing an Society: „ekonomia to studium praw własności do rzadkich zasobów [...]. Alokacja rzadkich zasobów w społeczeństwie jest bowiem zależna od praw do użytkowania zasobów [...]. Problemem

1 Trudno jednak sądzić, że omawiany dalej tradycyjny instytucjonalizm i nowa ekonomia instytucjonalna kwalifikują się do miana jednej ekonomii instytucjonalnej w rozumieniu wyodrębnionego kierunku opartego na wspólnym paradygmacie, czy też wspólnym stosunku do innych kierunków. Por. szerzej: M. Ratajczak, Miejsce instytucjonalizmu we wspótczesnej ekonomii, Materiały konferencyjne 55 Międzynarodowego Kongresu Ekonomistów Francuskojęzycznych pt. „Bilan et perspectives d'un demi-siècle de construction de l'Union européenne dans le cadre de la mondialisation économique contemporaine" zorganizowanego przez Association Internationale des Economistes de Langue Française i SGH w Warszawie, 21-23.05.2007, s. 9.

2 M.G. Woźniak, Fundamentalne problemy aksjologiczne tadu instytucjonalnego wspótczesnej gospodarki, [w: Ead instytucjonalny w gospodarce, t. II, red. B. Polszakiewicz i J. Boehlke, Wydawnictwo Uniwersytetu Mikołaja Kopernika, Toruń 2005, s. 21.

3 Ibidem. 
ekonomii jest zatem to [...] jak prawa własności powinny być zdefiniowane" ${ }^{4}$. Inaczej - chodzi tu m.in. o to, jak powinny być postrzegane pewne uwarunkowania instytucjonalne służące do prowadzenia wymiany ekonomicznej, w tym także wymiany na rynku pracy.

Nurt instytucjonalny tłumaczy przy tym nie tylko to, jak zachowuje się jednostka gospodarująca, ale również i to, dlaczego podejmuje takie, a nie inne decyzje. Zachowania podmiotów ekonomicznych zależą bowiem od instytucji, $\mathrm{w}$ ramach których one funkcjonują ${ }^{5}$. Jak twierdzi zaś jeden z przedstawicieli tradycyjnej ekonomii instytucjonalnej J.R. Commons, podstawową funkcją instytucji jest zapewnienie jednostkom możliwości współdziałania w świecie pełnym konfliktów ${ }^{6}$. Konflikty występują również na rynku pracy i stąd też instytucje muszą brać czynny udział w stanowieniu praw i obowiązków w zakresie np. wynagradzania pracowników, płacy minimalnej czy też zasiłków dla bezrobotnych. Funkcjonowanie tego typu instytucji może przynosić jednak także skutki negatywne dla rynku pracy i stanowić źródło bezrobocia. Chodzi tu przy tym o taki właśnie rodzaj bezrobocia, które w literaturze przedmiotu określone zostało mianem instytucjonalnego.

Zjawisko tego bezrobocia można bowiem „przypisać” pewnym zachowaniom występującym w ramach określonych ,instytucji”, obejmujących działania trzech głównych podmiotów funkcjonujących na rynku pracy. Pierwszą grupę stanowią tu sami pracodawcy, którzy wykazują się brakiem zainteresowania zatrudnianiem bezrobotnych i tym samym sprzyjają utrzymywaniu się długookresowego bezrobocia. Zachowania te moga zaś wynikać ze specyficznych bodźców skłaniających pracodawców i pracowników do zawierania np. długookresowych kontraktów o pracę. Bezrobotni mają przy tym odpowiednie kwalifikacje i mogliby podjąć pracę, ale pracodawcy z różnych powodów (takich jak np. siła insiders czy osiąganie wyższej wydajności za pomocą płacy motywacyjnej) preferują utrzymywanie już zatrudnionych pracowników (np. wydłużając ich czas pracy).

Druga grupa obejmuje $\mathrm{z}$ kolei zachowania pracowników, ponieważ to oni mogą również wyrażać niechęć do podjęcia pracy za ustalone wynagrodzenie, nawet jeśli są bezrobotnymi. Zjawisko to dostrzegał zresztą już sam John M. Keynes, wskazując, że wynika ono z „odmowy lub niemożności przyjęcia przez robotnika wynagrodzenia odpowiadającego krańcowej wydajności jego pracy. Nieprzyjęcie

\footnotetext{
4 Za: R.M. Jakubowski, Efektywność gospodarcza w ujęciu ekonomicznej teorii praw wtasnościwybrane zagadnienia, [w:] Ead instytucjonalny w gospodarce, t. II., red. B. Polszakiewicz i J. Boehlke, Wydawnictwo Uniwersytetu Mikołaja Kopernika, Toruń 2006, s. 67.

5 Por. M. Ratajczak, Nurt instytucjonalny we wspótczesnej myśli ekonomicznej, „Ruch Prawniczy, Ekonomiczny i Socjologiczny" 1994, z. 1.

6 Por. M. Iwanek, J. Wilkin, Instytucje i instytucjonalizm w ekonomii, Wydawnictwo UW-WNE, Warszawa 1998.
} 
wynagrodzenia odpowiadającego wartości produktu, które należy przypisać krańcowej wydajności pracy, może wynikać z ustawodawstwa, z ustalonych zwyczajów, ze zrzeszania się do zbiorowych przetargów o lepsze warunki pracy, z powolnej reakcji na zmianę warunków pracy lub po prostu z ludzkiego oporu"

Trzecia natomiast grupa zachowań wiąże się z działalnością państwa jako podmiotu gospodarującego, które również przyczyniać się może do wzrostu bezrobocia poprzez swoje ustawodawstwo i politykę gospodarczą (w postaci np. stanowienia płac minimalnych).

Bezrobocie instytucjonalne zaliczane jest przy tym (obok bezrobocia strukturalnego) do tzw. bezrobocia równowagi, które „nie znika” nawet w warunkach wzrostu gospodarczego i występuje w punkcie równowagi gospodarczej. Jest ono zatem nieodłącznym elementem funkcjonowania każdej gospodarki rynkowej podlegającej większym lub mniejszym przekształceniom strukturalnym i instytucjonalnym.

Przedmiotem bliższej analizy w niniejszym opracowaniu są zatem tak podstawy teoretyczne bezrobocia instytucjonalnego, jak i jego determinanty w praktyce gospodarowania. Mając na uwadze powyższe cele, zwrócimy tu też uwagę na to, czym są w ogóle instytucje w teorii ekonomii, a w ślad za tym i na rynku pracy.

\section{INSTYTUCJE W TEORII EKONOMII}

W nurcie instytucjonalnym wyróżnić można dwie podstawowe szkoły - tzw. starą ekonomię instytucjonalną (określaną często przez jej reprezentantów mianem klasycznego bądź historycznego instytucjonalizmu czy też neoinstytucjonalizmu) oraz tzw. nową ekonomię instytucjonalną ${ }^{8}$.

W ujęciu historycznym tradycyjna ekonomia instytucjonalna rozwinęła się w Stanach Zjednoczonych w latach 20.XX wieku, a jej wybitnymi reprezentantami stali się T.B. Veblen, J.R. Commons oraz W.C. Mitchell.

Przedstawiciele tej szkoły postulowali przede wszystkim „adaptacje” teorii Darwina dla potrzeb ekonomii oraz zastąpienie kategorii „racjonalnego człowieka” kategorią „agenta w otoczeniu instytucjonalnym”, który „kierowany” byłby także przez zwyczaje i rutynę. Przyjmowali oni bowiem, że działania osób są s. 32 .

J.M. Keynes, Ogólna teoria zatrudnienia, procentu i pieniądza, wyd. 2, PWN, Warszawa 1985,

A. Ząbkowicz, Wspótczesna ekonomia instytucjonalna wobec gtównego nurtu ekonomii, „Ekonomista" 2003, nr 6, s. 795-824; A. Hordecka, Instytucjonalizm i podejscie instytucjonalne do polityki gospodarczej, „Polityka Gospodarcza”, nr 5-6, Oficyna Wydawnicza SGH w Warszawie, Warszawa 2001-2002, s. 115-143. 
głównie zwyczajowe i tylko w części zamierzone oraz że mają one duże znaczenie dla rozprzestrzeniania się wiedzy i umiejętności podmiotów w społeczeństwie 9 .

W momencie zaś, gdy „zwyczaj” staje się powszechny i umacnia się w jakiejś społeczności lub grupie, przyjmuje on postać socjoekonomicznej instytucji ${ }^{10}$. Instytucje to bowiem - zdaniem T.B. Veblena - stabilne zwyczaje dotyczące pojmowania rzeczywistości, które są wspólne dla pewnej grupy podmiotów ${ }^{11}$. Inaczej można powiedzieć, że instytucje to sposoby myślenia i zarazem działania „zawarte” w zwyczajach pewnej grupy ludzi.

Z kolei J.R. Commons definiuje pojęcie „instytucji” jako „działające układy, razem ze swoimi regułami funkcjonowania, od rodziny, poprzez korporację, związek zawodowy, stowarzyszenie gospodarcze, aż do samego państwa"12.

W gospodarce zmiany instytucjonalne powstają przy tym na skutek dwóch przyczyn. Po pierwsze, podmioty gospodarcze dążąc do zwiększenia swojej ekonomicznej efektywności oraz zwiększenia strumienia dochodów, poszukują nowych rozwiązań instytucjonalnych. Po drugie - zmiany dokonują się w rezultacie przeobrażeń w kolektywnych relacjach wobec różnych problemów (np. akceptacja pracy nieletnich była kiedyś powszechna, a obecnie jest ograniczona $)^{13}$.

Poglądów z kolei nowej ekonomii instytucjonalnej poszukiwać należy w początkach lat 70. XX wieku, a jej czołowymi reprezentantami są tacy twórcy, jak np. R.H. Coase, O. Williamson, D.C. North czy G. von Schmoller ${ }^{14}$. Podobnie jak tradycyjny instytucjonalizm, szkoła ta podkreśla oddalenie klasycznej i neoklasycznej teorii ekonomii ${ }^{15}$ (jako posługującej się „walrasowskim obrazem” gospodarki i bardzo uproszczonym modelem, jakim jest w pełni racjonalny homo oeconomicus) od współczesnej praktyki gospodarczej. Uznaje ona przy tym, że zachowania jednostek mają swój wpływ na kształtowanie się instytucji, w przeci-

9 T. Gaweł, M. Klimczak, Pojęcie instytucji w prawie i ekonomii, [w:] Ead instytucjonalny w gospodarce, t. II, s. 78.

10 Pojęcie „instytucja” pochodzi od łacińskiego słowa institutiones, co oznaczało opracowanie zawierające podstawowe informacje z dziedziny prawa mające charakter informacyjno-dydaktyczny, a to $\mathrm{z}$ kolei pochodziło od pojęcia instituere, co oznaczało udzielenie wstępnych wiadomości osobom rozpoczynającym studia prawnicze. Por. Prawo rzymskie. Stownik encyklopedyczny, red. W. Wołodkiewicz, Wiedza Powszechna, Warszawa 1986, s. 74.

11 T. Veblen, The Place of Science in Modern Civilisation and Other Essays, BW Huesbsch, New York 1919, s. 239.

12 J.R. Commons, Institutional Economics. Its Place in Political Economy, t. 1, New York 1934, s. 146

13 M. Ratajczak, Instytucjonalizm - wzbogacenie czy alternatywa ekonomii gtównego nurtu?, [w:] Ead instytucjonalny w gospodarce, t. II, s. 62.

14 Dwaj ostatni są przedstawicielami nowej historii gospodarczej traktowanej jako część składowa szeroko rozumianej nowej ekonomii instytucjonalnej.

15 Por. m.in. W. Jarmołowicz, K. Szarzec, Funkcjonowanie rynku pracy w świetle wspótczesnych doktryn ekonomicznych, [w:] Przemiany na wspótczesnym rynku pracy, red. W. Jarmołowicz, Wydawnictwo „Forum Naukowe”, Poznań 2008, s. 13-29. 
wieństwie do tradycyjnego instytucjonalizmu, który twierdził, że to właśnie instytucje kształtują zachowania podmiotów gospodarujących ${ }^{16}$.

Według reprezentantów nowej ekonomii instytucjonalnej, takich jak np. G. von Schmoller, instytucje to zestaw formalnych i nieformalnych zasad wraz z mechanizmami służącymi ich egzekwowaniu.

Z kolei według D.C.Northa system instytucjonalny złożony jest nie tylko $\mathrm{z}$ instytucji formalnych i nieformalnych, ale również z tzw. stopnia przestrzegania ukształtowanych reguł ${ }^{17}$. Instytucje formalne to przy tym różnorodne normy prawne, takie jak np. prawo do pracy oraz wszelkie prawa zawarte w takim akcie jak konstytucja, kodeks czy też w innych regulacjach (statutach) dotyczących jakiejkolwiek organizacji (np. przedsiębiorstwa, banku, związku zawodowego, klubu sportowego etc.). Instytucje nieformalne to z kolei te reguły "gry” życia społecznego, które obejmują zasady kształtujące społeczne interakcje (takie np. jak zwyczaje, obyczaje, zasady etyczne, elementy mentalne, etc.). Instytucje te jako kształtujące się „przez lata”, powielane są też przez zachowania jednostek i dostosowywane do zmieniającego się otoczenia zgodnie z regułą racjonalnego wyboru, choć bywają też irracjonalne. Przejawami tych instytucji są zarazem nie tylko ujęcia formalne (reguły, prawo, organizacja etc.), ale także nieformalne ograniczenia (takie np. jak normy zachowań, konwencje etc.) ${ }^{18}$.

Szczególnie przy tym upowszechnionym sposobem pojmowania instytucji jest ich utożsamianie $z$ pojęciem i działaniem organizacji. Terminem tym - przynajmniej w polskim ustawodawstwie - obejmuje się zaś zwykle jednostkę instytucjonalną, pojętą jako elementarne centrum podejmowania decyzji gospodarczych, a charakteryzującą się jednolitym systemem rachunkowości oraz autonomią w podejmowaniu decyzji związanych ze spełnianiem jej podstawowych funkcji ${ }^{19}$.

Zdaniem D.C. Northa wszelkie organizacje i instytucje to zarazem dwa odrębne „byty”. Organizacje to bowiem grupy podmiotów lub osób, dążących do osiągnięcia przyjętego celu, który jest zarazem źródłem zmiany instytucjonalnej ${ }^{20}$.

\footnotetext{
16 G.M. Hodgson, The Approach of Institutional Economics, "Journal of Economic Literature” 1998, vol. XXXVI, s. 176.

17 D.C. North, Institutional Change: A Framework of Analysis, http://ideas.repec.com (data dostępu 12.12.2009); idem, Institutions, Institutional Change, and Economic Performance, Cambridge University Press, New York 1990, cyt. za: A. Ziomek, Instytucje rynku pracy uwarunkowaniem wzrostu gospodarczego, [w:] Ekonomiczne i spoteczne determinanty wzrostu gospodarczego, red. W. Jarmołowicz, Zeszyty Naukowe, Wydawnictwo UE w Poznaniu, Poznań 2009, nr 121, s. 73.

18 D.C. North, Institutions, s. 73.

19 Dz.U. 0433289 Polska Klasyfikacja Działalności (PKD).

20 Warto jednak zaznaczyć, że nie każda organizacja może być traktowana jako instytucja. Tak np. Światowa Organizacja Handlu czy Unia Europejska nie są instytucjami, ale już fundusz hedgingowy czy związek zawodowy mogą nimi być. Por. R. Connor, S. Dovers, Institutional Change for Sustainable Development, Edward Elgar Publishing, Cheltenham, UK, Northampton, MA 2004, s. 11.
} 
Podstawową różnicą między tradycyjnym instytucjonalizmem a nową ekonomią instytucjonalną jest przede wszystkim to - jak podkreśla J. Małysz - że ten pierwszy od swego zarania tworzony był z myślą o tym, że będzie alternatywą wobec ekonomii neoklasycznej, podczas gdy nowa ekonomia instytucjonalna stawia sobie raczej zadanie bycia tylko jej istotnym uzupełnieniem ${ }^{21}$.

Tradycyjny instytucjonalizm podnosi zarazem w sferze metodologicznej potrzebę zajmowania stanowiska holistycznego i długookresowego, a także traktowania ekonomii jako nauki empirycznej i politycznej ${ }^{22}$. Akceptuje przy tym celowość zachowywania aktywnej roli państwa w gospodarce, przy jednoczesnym zachowaniu atrybutów gospodarki rynkowej, chociaż przy akcentowaniu tezy, że nie ma jednej gospodarki rynkowej ze względu na zróżnicowanie warunków instytucjonalnych ${ }^{23}$.

Różnica pomiędzy tradycyjnym i współczesnym podejściem instytucjonalnym widoczna jest także w przedmiocie badań. W tym pierwszym obszar badań jest rozległy i mało konkretny, a jego podstawę stanowią również instytucje niesformalizowane, takie chociażby jak obyczaje czy też tradycja bądź rytuał. Natomiast $\mathrm{w}$ drugim przedmiotem badań są wyraźnie określone transakcje zawierane pomiędzy podmiotami ekonomicznymi ${ }^{24}$.

Uogólniając powyższe uwagi i odnosząc je do przedmiotu zainteresowań na rynku pracy, można zauważyć, że tradycyjny instytucjonalizm, którego przedmiotem badań jest właśnie ścisłość związków instytucji ekonomicznych i pozaekonomicznych, ale także inercja tych instytucji oraz złożoność motywów działalności ludzkiej także w sferze ekonomicznej, jak również powiązania władzy politycznej i ekonomicznej ${ }^{25}$; staje się również „zapleczem” teoretycznym dla analiz rynku pracy. Jednocześnie również w nowej ekonomii instytucjonalnej idee ograniczonej racjonalności i oportunizmu odnoszone do zachowań podmiotów ekonomicznych czy też wnioski płynące $\mathrm{z}$ analizy kosztów transakcyjnych mogą być istotną podstawą badania rynku pracy na poziomie mikroekonomicznym i objaśniającym motywy działania podmiotów ekonomicznych.

21 J.Małysz, Instytucje a koszty transakcyjne w świetle neoinstytucjonalnej ekonomii, „Ekonomista” 2003, nr 3, s. 315 i 317.

22 Por. K. Dopfer, Wprowadzenie: Ku nowemu paradygmatowi, [w:] Ekonomia w przysztości, red. K. Dopfer, PWN, Warszawa 1982, s. 19-66.

23 W.C. Neale, Society, state and market: A Polanyian view of current change and turmoil in eastern Europe, „Journal of Economic Issues” 1991, vol. XXV, No. 2, s. 470, za: M. Ratajczak, Miejsce instytucjonalizmu we wspótczesnej gospodarce, s. 6.

24 M. Lissowska, Instytucjonalne wymiary procesu transformacji w Polsce, Oficyna Wydawnicza SGH w Warszawie, Warszawa 2004, s. 40.

25 M. Ratajczak, Instytucjonalizm - wzbogacenie czy alternatywa ekonomii gtównego nurtu?, s. 71 . 
Uwzględniając odmienności wypływające z założeń omówionych wyżej szkół ekonomii instytucjonalnej, a mających także znaczenie dla analizy rynku pracy, celowe wydaje się tu więc bliższe jeszcze sprecyzowanie poglądów na temat pojęcia „instytucja” - jako istotnie głównej kategorii społeczno-ekonomicznej systemu instytucjonalnego. Pojęciu temu nadać zatem można trojakiego rodzaju znaczenie ${ }^{26}$ :

a) prawnicze - są to bowiem reguły postępowania lub zachowania społeczne ustanowione zwyczajem, tzn. mające długą tradycję popartą społeczną akceptacją i w ten sposób stające się częścią prawa danego kraju;

b) ekonomiczne - gdy mówimy o grupie osób złączonych wspólnym celem z organizacją lub o systemie ustanowionym dla osiągnięcia celów gospodarczych;

c) finansowe - w rozumieniu - duże i ważne jednostki w systemie gospodarczym.

\section{INSTYTUCJE NA RYNKU PRACY A BEZROBOCIE INSTYTUCJONALNE}

Jednym $z$ istotnych obszarów gospodarki rynkowej jest rynek pracy, gdzie zawierane są transakcje kupna i sprzedaży usługi pracy. Transakcje te są regulowane - jak to już wcześniej podkreślano - przez szereg instytucji, które tworzą wzajemne i wiarygodne zobowiązania w kwestii ustaleń płacowych, zatrudnienia, czy współpracy między firmami. Instytucjami są tu także same związki pracowników oraz pracodawców, jak i organy państwa. Zatem kluczową rolę w kształtowaniu sytuacji na rynku pracy odgrywają instytucje tego rynku.

Analizując kwestię instytucji według nowej ekonomii instytucjonalnej w aspekcie funkcjonowania samego rynku pracy, należy też podkreślić, że głównym ich zadaniem jest lepsze kojarzenie popytu na pracę $\mathrm{z}$ podażą wolnych miejsc pracy. Chodzi tu zwłaszcza o efektywne dostosowania, gdzie podstawowe znaczenie mają takie czynniki instytucjonalne jak: prawo pracy, funkcjonowanie urzędów pracy, stopień ochrony zatrudnienia, system negocjacji, zabezpieczenie społeczne czy też poziom płacy minimalnej oraz inne.

Wypada też dostrzegać, że na rynku pracy pracodawcy i pracobiorcy zmuszeni są do stałych i wzajemnych poszukiwań pracowników i miejsc pracy, co odbywa się $\mathrm{w}$ warunkach asymetrii informacji. Rolą instytucji na takim rynku pracy jest zatem także zminimalizowanie zjawisk towarzyszących tej asymetrii, a jednocześnie niepowodujących wzrostu kosztów transakcyjnych.

26 A. Kubiczek, Instytucjonalne uwarunkowania zmian na rynku pracy, [w:] Ead instytucjonalny w gospodarce, t. II, s. 126. 
Wśród samych zaś instytucji rynku pracy - w ślad za ustaleniami nowej ekonomii instytucjonalnej - szczególną uwagę wypada przy tym zwrócić na dwa szczególnie ważne typy „instytucji”, które związane są z kwestią własności oraz wymiany, a jednocześnie objaśniają zachowania pracodawców na rynku pracy. Instytucje te znalazły też swoje rozwinięte ujęcia w teoriach: kosztów transakcyjnych, praw własności i agencji.

I tak, teoria kosztów transakcyjnych jako powstała na gruncie analizy znaczenia procesu powstawania przedsiębiorstwa i objaśniania tego, dlaczego w systemie gospodarki wolnorynkowej robotnik dobrowolnie poddaje się władzy przedsiębiorcy, podkreśla, że transakcje nie są tu rozumiane jako „wymiana towarów”, lecz jako „alienacja i pozyskiwanie między jednostkami praw własności i wolności stworzonych przez społeczeństwo. W skutkach oznacza to, że zainteresowane strony muszą podjać negocjacje zanim jeszcze „praca” - coś wyprodukuje, konsumenci - coś skonsumują, a towary zostaną fizycznie wymienione"27. Koszty transakcyjne to zatem ta część łącznych kosztów funkcjonowania systemu społeczno-gospodarczego, która obejmuje nakłady zasobów ponoszone $\mathrm{w}$ trakcie zawierania i realizacji wszystkich typów transakcji ${ }^{28}$. Przy tym zdaniem R.H. Coase'a przyczyną dobrowolnego poddawania się pracowników władzy pracodawców są właśnie wysokie koszty transakcyjne, inaczej koszty funkcjonowania rynku pracy. Pracodawca unika ponoszenia kosztów wielu negocjacji i szacowania cen powstających w rozlicznych transakcjach. Musi jedynie wybrać odpowiedni rodzaj kontraktu ${ }^{29}$. Stąd też - wraz z teorią kosztów transakcyjnych - ważne miejsce we współczesnej ekonomii instytucjonalnej zajmuje teoria kontraktów. Kontrakt to umowa, układ między stronami, prezentujący warunki i zobowiązania oraz terminy realizacji. Kontrakt może być zatem rozumiany jako znacząca instytucja w całej strukturze instytucjonalnej współczesnego systemu społeczno-gospodarczego, ściśle powiązana $z$ mechanizmem rynkowym i z funkcjonowaniem całego rynku pracy ${ }^{30}$.

Kwestię zawierania długookresowych kontraktów o pracę porusza też inna jeszcze teoria zaliczana do nowej ekonomii instytucjonalnej, a mianowicie teoria agencji. Poszukuje ona bowiem również - podobnie jak teoria kosztów transakcyjnych - odpowiedzi na pytanie: dlaczego we współczesnych gospodarkach rynkowych podmioty gospodarcze preferują kontrakty o pracę, a tym samym godzą się na występowanie pewnego rodzaju bezrobocia instytucjonalnego. Punktem wyjścia tej koncepcji jest zaś tzw. kwestia „agencji”, która powstaje wówczas,

\footnotetext{
27 J.R. Commons, op. cit., s. 652.

28 W. Stankiewicz, Ekonomika instytucjonalna. Zarys wyktadu, Wydawnictwo PWSBiA, Warszawa 2005, s. 80.

29 Ibidem, s. 24-25.

30 J.R. Commons, op. cit., s. 652.
} 
gdy jeden podmiot jest zależny od działalności drugiego, któremu zleca zadanie do wykonania. Pierwszym przy tym powodem, dla którego dochodzi do relacji zachodzących w płaszczyźnie „agencji”, jest asymetria informacji. Zakłada się bowiem, że agent wie więcej o wykonywanych zadaniach niż zwierzchnik. Drugim powodem jest natomiast rozbieżność funkcji celu zwierzchnika i agenta. Problem agencji powoduje zatem powstawanie określonych kosztów agencji (takich jak: koszty monitorowania agenta przez zwierzchnika oraz koszty jakie musi ponieść agent, by stać się dla zwierzchnika wiarygodnym, czy też straty powstające w sytuacji, gdy zwierzchnikowi nie udaje się skłonić agenta do działania zgodnego z jego celami). Rozwiązaniem instytucjonalnym problemu agencji jest przy tym właśnie stworzenie transakcji o określonej strukturze kontraktu, gdzie zwierzchnik tak konstruuje umowę, by motywować agenta do działań jak najbardziej zgodnych ze swoim interesem, np. przez odpowiednie określenie zasad wynagrodzenia (teoria płacy motywującej). Pojawia się tu zatem sytuacja, kiedy to nawet w warunkach wzrostu gospodarczego, część pracodawców woli utrzymywać wysokie płace i ograniczać nowe zatrudnienie, co w konsekwencji prowadzi do utrzymywania się - w miarę trwałego - bezrobocia o charakterze instytucjonalnym ${ }^{31}$.

Ponadto dostrzegać tu również należy, że wpływ na decyzje poszczególnych grup podmiotów na rynku pracy wywierają nie tylko warunki ekonomiczno-finansowe i techniczno-organizacyjne, ale także istniejące zwyczaje, doświadczenia i powszechnie uznane normy, co w sumie tworzy też pewien poziom tzw. kapitału społecznego. Kapitał ten to bowiem swoistego rodzaju „majątek” sieci społecznych ${ }^{32}$. Na kapitał społeczny składa się więc m.in. zdolność ludzi do współpracy i współdziałania (w tym umiejętność samoorganizowania dla realizacji wspólnych celów). Wartość tego kapitału zmienia się przy tym wraz ze zmianą więzi międzyludzkich, a podstawowymi jego wyznacznikami są: zaufanie, normy społeczne, sieci społecznych relacji i powiązań ${ }^{33}$. I tak np. kapitał społeczny rośnie, gdy dominują etyczne wzorce zachowań takie jak: przedsiębiorczość, pracowitość i uczciwość, natomiast maleje, gdy dominuje roszczeniowość, praktyki bumelowania w pracy czy oportunistycznych zachowań.

31 W. Stankiewicz, op. cit., s. 24-25, 80; K. Sobiech, B. Woźniak, Ekonomia instytucjonalna, [w:] Wspótczesne teorie ekonomiczne, red. M. Ratajczak, Wydawnictwo AE w Poznaniu, Poznań 2005, s. $133-157$.

32 N. Lin, Building a Network Theory of Social Capital, [w:] Social Capital. Theory and research, red. N. Lin, K. Cook, R. Burt, Aldine De Gruyter, New York 2001, s.17.

33 R. Putnam, R. Leonardi, R. Nanetti, Making Democracy Work: Civic Traditions in Modern Italy, Princeton Univeristy Press, Princeton 1993, s. 167. 


\section{DETERMINANTY BEZROBOCIA INSTYTUCJONALNEGO W PRAKTYCE GOSPODAROWANIA}

Poprawna identyfikacja i kwantyfikacja bezrobocia instytucjonalnego rodzi różne trudności, niemniej możliwe staje się wskazanie jego „sprawców” w postaci głównych „instytucji” występujących w otoczeniu pracodawców oraz pracowników, które prawdopodobnie wpływają właśnie na powstawanie tego rodzaju bezrobocia. Trzeba przy tym zauważyć, że „instytucje” te są jednocześnie „projektowane” oraz „nadzorowane” przez trzeci podmiot uznany za źródło bezrobocia instytucjonalnego, a mianowicie - państwo.

Analizując więc bardziej już od strony praktycznej determinanty bezrobocia instytucjonalnego, wskazać można, że mogą nimi być przykładowo zwłaszcza następujące:

a) w sferze zachowań pracodawców:

- deformacje rynku pracy - rozumiane jako m.in. rygorystyczne, sztywne formy zatrudnienia oraz rozwiązania legislacyjno-finansowe, które nie zachęcają przedsiębiorców do zwiększania elastycznych form zatrudnienia oraz zmuszają do ponoszenia stosunkowo wysokich pozapłacowych kosztów pracy (inaczej niska elastyczność warunków pracy);

- utrzymywanie się znacznego zakresu własności państwa w wielu ważnych gałęziach gospodarki i przez to wpływanie na sytuacje gospodarcza (w tym i na rynku pracy oraz w innych sektorach) w sposób sprzyjający powstawaniu bezrobocia (np. przez utrzymywanie „stałego zatrudnienia”);

- wysoki stopień zbiurokratyzowania gospodarki oraz niska sprawność administracji państwowej przyczyniające się do nadmiernej „sztywności" rynku pracy;

- bariery biurokratyczne rozwoju przedsiębiorczości;

b) w sferze zachowań pracowników:

- formy zabezpieczenia społecznego i ustawowe wydatki socjalne, osłabiające intensywność poszukiwań pracy przez bezrobotnych (czyli nadmierna „hojność” systemu zabezpieczenia socjalnego);

- występowanie i wysokość płacy minimalnej;

- silna pozycja związków zawodowych wynikająca z siły insiders czy też wysokich kosztów rotacji pracowników, zwłaszcza w sektorze państwowym;

- istnienie szarej strefy i jej zakres;

- niedostosowanie profilu wykształcenia do potrzeb rynku pracy;

- niska mobilność zawodowa czy też przestrzenna pracowników (np. z powodu słabo rozwiniętej edukacji dorosłych);

- brak wsparcia rodziny w poszukiwaniu pracy etc. 
Zwalczanie zjawiska bezrobocia instytucjonalnego wymaga zatem takiego kształtowania odpowiedniego otoczenia dla działających na rynku pracy podmiotów, w ramach którego wykorzystane zostaną różne narzędzia prawno-ekonomiczne służące ograniczaniu lub przeciwdziałaniu negatywnym skutkom źle „działających” instytucji rynku pracy. Chodzi tu m.in. o takie np. instrumenty, jak: efektywne pośrednictwo pracy, system podatkowy „przyjazny” dla przedsiębiorców tworzących nowe miejsca pracy i inne.

Problem bezrobocia instytucjonalnego wiąże się też z zakresem działalności państwa w obszarze rynku pracy. Już przedstawiciele tradycyjnej ekonomii instytucjonalnej opowiadali się za ingerencją państwa w funkcjonowanie rynku pracy, ale jednak w mniejszym stopniu przy wykorzystaniu działań bezpośrednich, a w większym - przez zastosowanie instrumentów pośrednich, takich np. jak: negocjacje ze związkami zawodowymi i organizacjami pracodawców.

Podkreślają oni, że również niewłaściwa polityka monetarna i fiskalna czy też nieodpowiedni system zabezpieczenia społecznego może powodować pojawienie się takich to „niedoskonałości” rynku pracy, jak bezrobocie instytucjonalne. Chodzi tu np. zwłaszcza o dezaktywizujący system świadczeń społecznych, w takim sensie, że sprzyja on osobom w wieku przedemerytalnym w przechodzeniu na wcześniejsze emerytury, zasiłki przedemerytalne lub renty. Tym samym wymusza on wysokie, pozapłacowe koszty pracy niezbędne do pokrycia rosnących świadczeń socjalnych, które finansują z kolei osoby pracujące i pracodawcy jako odprowadzające do budżetu państwa wyższe podatki. Taka sytuacja „przekłada się” na spadek zarówno popytu na pracę, jak i chęci podejmowania pracy, zwłaszcza wówczas, gdy państwo oferuje znaczne świadczenia socjalne ${ }^{34}$.

Ponadto zasadne jest dostrzeganie takiego jeszcze aspektu zmian instytucjonalnych na rynku pracy, który dotyczy ewolucji tradycyjnego stosunku pracy jako dominującej formy regulowania pracy najemnej w ramach przedsiębiorstwa. Rośnie bowiem znaczenie nowych form w tej płaszczyźnie, takich np. jak: praca $\mathrm{w}$ niepełnym wymiarze, praca na czas określony, telepraca czy praca tymczasowa etc. Ta „transformacja” form zatrudnienia to przy tym $z$ jednej strony efekt przemian w ramach zmian systemu gospodarczego i dostosowywania się stron zawierających „transakcje” do wymogów zmieniającego się rynku pracy ${ }^{35}$, a $z$ drugiej - metoda ograniczania bezrobocia instytucjonalnego przez "uelastycznienie” wymiany na tymże pracy.

34 B. Woźniak, Naturalna stopa bezrobocia w Polsce - rezultat swobodnego wyboru jednostek czy zawodności dziatania rynku, [w:] Liberalizm we wspótczesnej gospodarce, red. W. Jarmołowicz, M. Ratajczak, Wydawnictwo AE w Poznaniu, Poznań 2008, s. 264-285.

35 M. Moszyński, Praca tymczasowa w świetle teorii kosztów transakcyjnych, [w:] Ead instytucjonalny w gospodarce, t. II, s. 461. 


\section{ZAKOŃCZENIE}

Bezrobocie instytucjonalne jest nowym, i - jak dotąd - wciąż nie w pełni rozpoznanym rodzajem bezrobocia.

Ogólniej we współczesnym i dość powszechnie akceptowanym ujęciu (zaproponowanym przez J.C. Haltiwangera ${ }^{36}$ ) bezrobocie instytucjonalne to szerokie pojęcie, które za swe źródła przyjmuje - obok zachowań pracowników - również określone zachowania pracodawców (znajdujące uznanie u już zatrudnionych sił insiders), które prowadzą do zawierania $\mathrm{z}$ nimi długookresowych kontraktów o pracę oraz do stosowania wobec nich wysokich stawek płac efektywnych czy też do innych jeszcze porozumień, będących jednocześnie formą swoistej „dyskryminacji” bezrobotnych (w sensie braku zainteresowania ich zatrudnieniem) ${ }^{37}$.

Doceniając - ramowo - powyższą definicję, sądzimy tu jednak, że warto także podkreślić i rozwinąć pogląd, że źródła bezrobocia instytucjonalnego są trojakiego rodzaju. Po pierwsze wtedy, gdy przedsiębiorstwa nie są zainteresowane zatrudnianiem bezrobotnych nie tylko w warunkach dekoniunktury, ale nawet w okresach wzrostu gospodarczego. Wynikać to zaś może ze wskazywanych wyżej, specyficznych kontraktów związanych z wykonywaniem pracy. Po drugie, że bezrobocie instytucjonalne powodowane być może zachowaniem samych bezrobotnych, którzy działają w określonym środowisku instytucjonalnym. Po trzecie zaś, że bezrobocie instytucjonalne może mieć swoje przyczyny również w działaniach samego państwa ${ }^{38}$. Ma ono przy tym charakter dobrowolny, gdyż to podmioty gospodarcze "projektują” i „tworzą” różnego typu instytucje, które mogą - i nawet wbrew intencjom ich twórców - przyczyniać się do jego powstawania.

Aby zwalczać bezrobocie instytucjonalne, polityka gospodarcza (wykorzystując różne narzędzia prawno-ekonomiczne) powinna sprzyjać przede wszystkim jak najszybszemu przechodzeniu bezrobotnych w stan zatrudnienia, czyli także „przekierowywać" ludzi od systemu pomocy socjalnej do sfery pracy ${ }^{39}$. Brak takich działań czy też ich niska skuteczność powoduje natomiast, że bezrobocie instytucjonalne zaczyna mieć charakter długookresowy, państwo zaś - zamiast stosowania instrumentów aktywnego przeciwdziałania bezrobociu - wykorzystu-

36 Por. J.C. Haltiwanger, The Natural Rate of Unemployment, [w:] The Nerw Palgrave A Dictionary of Economics, The Macmillan Press Ltd., Cambridge 1987.

37 M. Socha, U. Sztanderska, Strukturalne podstawy bezrobocia w Polsce, Wydawnictwo Naukowe PWN, Warszawa 2000, s. 25.

38 Szerzej na ten temat por. W. Jarmołowicz, B. Woźniak, Transformacyjne bezrobocie instytucjonalne, [w:] Bezrobocie we wspótczesnych gospodarkach rynkowych, red. D. Kopycińska, Wydawnictwo Naukowe Uniwersytetu Szczecińskiego, Szczecin 2006, s. 51-65.

39 Por. bliżej S. Nickell, R. Layard, Labour Market Institutions and Economic Performance, „CEPR Discussion Papers”, nr 407, LSE, London 1998, s. 70. 
je narzędzia pasywne, co w skutkach potęguje jeszcze bardziej analizowane tu zjawisko społeczno-gospodarcze.

\section{BIBLIOGRAFIA}

\section{POZYCJE ZWARTE}

Bezrobocie we wspótczesnych gospodarkach rynkowych, red. D. Kopycińska, Wydawnictwo Naukowe Uniwersytetu Szczecińskiego, Szczecin 2006.

Commons J.R., Institutional Economics. Its Place in Political Economy, t. 1, New York 1934. Ekonomiczne i spoteczne determinanty wzrostu gospodarczego, red. W. Jarmołowicz, Zeszyty Naukowe, Wydawnictwo UE w Poznaniu, Poznań 2009.

Ekonomia w przysztości, red. K. Dopfer, PWN, Warszawa 1982.

Hordecka A., Instytucjonalizm i podejscie instytucjonalne do polityki gospodarczej, „Polityka Gospodarcza”, nr 5-6, Oficyna Wydawnicza SGH w Warszawie, Warszawa 20012002.

Iwanek M., Wilkin J., Instytucje i instytucjonalizm w ekonomii, Wydawnictwo UW-WNE, Warszawa 1998.

Keynes J.M., Ogólna teoria zatrudnienia, procentu i pieniądza, wyd. 2, PWN, Warszawa 1985.

Liberalizm we wspótczesnej gospodarce, red. W. Jarmołowicz, M. Ratajczak, Wydawnictwo AE w Poznaniu, Poznań 2008.

Lissowska M., Instytucjonalne wymiary procesu transformacji w Polsce, Oficyna Wydawnicza SGH w Warszawie, Warszawa 2004.

Ead instytucjonalny w gospodarce, red. B. Polszakiewicz i J. Boehlke, Wydawnictwo Uniwersytetu Mikołaja Kopernika, Toruń 2005.

Ead instytucjonalny w gospodarce, t. II, red. B. Polszakiewicz i J. Boehlke, Wydawnictwo Uniwersytetu Mikołaja Kopernika, Toruń 2006.

Prawo rzymskie. Stownik encyklopedyczny, red. W. Wołodkiewicz, Wiedza Powszechna, Warszawa 1986.

Przemiany na wspótczesnym rynku pracy, red. W. Jarmołowicz, Wydawnictwo „Forum Naukowe", Poznań 2008.

Putnam R., Leonardi R., Nanetti R., Making Democracy Work: Civic Traditiobs in Modern Italy, Princeton Univeristy Press, Princeton 1993.

Socha M., Sztanderska U., Strukturalne podstawy bezrobocia w Polsce, Wydawnictwo Naukowe PWN, Warszawa 2000.

Social Capital. Theory and research, red. N. Lin, K. Cook, R. Burt, Aldine De Gruyter, New York 2001.

Stankiewicz W., Ekonomika instytucjonalna. Zarys wyktadu, Wydawnictwo PWSBiA, Warszawa 2005.

The New Palgrave A Dictionary of Economics, The Macmillan Press Ltd., Cambridge 1987. 
Veblen T., The Place of Science in Modern Civilisation and Other Essays, BW Huesbsch, New York 1919.

Wspótczesne teorie ekonomiczne, red. M. Ratajczak, Wydawnictwo AE w Poznaniu, Poznań 2005.

\section{ARTYKUŁY}

Hodgson G.M., The Approach of Institutional Economics, "Journal of Economic Literature” 1988, vol. XXXVI.

Małysz J., Instytucje a koszty transakcyjne w świetle neoinstytucjonalnej ekonomii, „Ekonomista" 2003, nr 3.

Neale W.C., Society, state and market: A Polanyian view of current change and turmoil in eastern Europe, „Journal of Economic Issues”1991, vol. XXV, No. 2.

Nickell S., Layard R., Labour Market Institutions and Economic Performance, „CEPR Discussion Papers", nr 407, LSE, London 1998.

Ratajczak M., Miejsce instytucjonalizmu we wspótczesnej ekonomii, Materiały konferencyjne 55 Międzynarodowego Kongresu Ekonomistów Francuskojęzycznych pt. „Bilan et perspectives d'un demi-siècle de construction de l'Union européenne dans le cadre de la mondialisation économique contemporaine" zorganizowanego przez Association Internationale des Economistes de Langue Française i SGH w Warszawie, 21-23.05.2007 r.

Ratajczak M., Nurt instytucjonalny we wspótczesnej myśli ekonomicznej, „Ruch Prawniczy, Ekonomiczny i Socjologiczny"1994, z. 1.

Ząbkowicz A., Wspótczesna ekonomia instytucjonalna wobec gtórwnego nurtu ekonomii, „Ekonomista" 2003, nr 6.

\section{INSTITUTIONAL UNEMPLOYMENT IN THEORY AND PRACTICE}

SUMMARY

The Institutional approach contributes significantly to the contemporary science of economy. It brings new ideas regarding fundamental aspects of the role of this science in society in general and its position in the social process of taking economic decisions in particular. An important part of this field is everything that can be related to the labour market and unemployment.

The main target of this dissertation is therefore to determine the nature as well as causes and effects of so called institutional unemployment. This phenomenon will be analyzed based on the main thesis and assumptions of institutional theory in the science of economics. 